\title{
An Integrated Retailer Image and Brand Equity Framework: Re-examining, Extending, and Restructuring Retailer Brand Equity
}

\author{
Johan Anselmsson (Lund University) \\ Steve Burt (University of Stirling) \\ Burak Tunca (University of Agder)
}

Accepted refereed manuscript of:

Anselmsson J, Burt S \& Tunca B (2017) An integrated retailer image and brand equity framework: Re-examining, extending, and restructuring retailer brand equity, Journal of Retailing and Consumer Services, 38, pp. 194-203.

DOI: $10.1016 /$ j.jretconser.2017.06.007

(C) 2017, Elsevier. Licensed under the Creative Commons AttributionNonCommercial-NoDerivatives 4.0 International

http://creativecommons.org/licenses/by-nc-nd/4.0/ 


\begin{abstract}
Retailers are amongst the world's strongest brands, but little is known about retailer brand equity. In spite of their extensive use, we argue that current operational models are too abstract for understanding the uniqueness of the retail industry and too simplistic to understand the interrelationships among the dimensions in the retailer brand equity building process. This study contributes to the existing and largely generic retailer equity frameworks in three ways: first, by incorporating retail specific dimensions from the retailer image literature; second, by reexamining and developing the structures and relationships between the dimensions of retailer equity by testing alternative structures commonly used in the more general brand equity literature; and finally by creating a short and parsimonious scale for assessing retailer brand equity in different contexts. Three alternative models are compared and tested on six brands in both convenience and shopping goods categories, ranging from discount to middle range price levels. The outcome is an operational framework supporting the conceptual brand resonance model presented in Keller (2001) and with seven dimensions structured in a four-step sequence as awareness $\rightarrow$ pricing policy, customer service, product quality, physical store $\rightarrow$ retailer trust $\rightarrow$ retailer loyalty, thereby describing retailer brand equity as a four-step process. The extended, although parsimonious, 17-item retailer equity scale can be used by academics as well as practitioners to examine the underlying values of retailer brands and has the potential to incorporate additional dimensions and attributes to investigate specific retail contexts without creating lengthy questionnaires.
\end{abstract}

Keywords: Retailer image, store image, brand equity, retailer equity, retailer trust 


\section{Introduction}

Several of the most valuable brands in the world are retailers. For instance, in the Interbrand (2016) listing of the top 30 global brands, four are pure retail brands (Amazon, H\&M, IKEA, Zara) and another ten can be related to retailing either through flagship stores or branded dealerships (e.g., Apple, Nike, Samsung, Toyota). A similar pattern is found in the BrandZ (2016) ranking, which also includes retailers like the Alibaba group, Home Depot, and Walmart. The strategic importance of branding for retailers has been repeatedly highlighted in retail management research (e.g., Burt, 2000; Jara \& Cliquet, 2012; Pappu \& Quester, 2006). One crucial aspect of strategic branding is understanding, measuring, and evaluating brand equity (Keller, 1993). Brand equity is an important concept for retailers given its association with purchase behavior, market share, financial performance, and shareholder value (Aaker, 1991; Anselmsson \& Bondesson, 2015; Keller \& Lehmann, 2003; Srivastava et al, 1998; Swoboda et al, 2016). Given the intensified competition in the retail industry, a better understanding of retailer brand equity is strategically important for both retail management and retail performance (Arnett et al, 2003; Das et al, 2012; Keller, 2010; Londoño et al, 2017; Swoboda et al, 2013).

The current conceptual and operational brand equity models capture various dimensions such as awareness, associations to quality and service, symbolic values, and consumer responses like trust and loyalty (Aaker, 1996; Keller, 2001). There are several examples of retailer equity scales, but because these scales are based on general models, they currently fail to capture important dimensions that are unique to the retailing industry. One major limitation of applying general brand equity models is that as they have been developed with the ambition of being universally applicable (e.g., Aaker, 1991; Yoo \& Donthu, 2001; Yoo et al, 2000), they are often less useful for understanding specific industries (Anselmsson et al, 2007). Hence, many brand 
equity studies have focused on specific businesses (see, Anselmsson et al, 2007; Lassar et al, 1995; Martin \& Brown, 1990; Washburn \& Plank, 2002). We therefore argue that retailer specific dimensions should be better reflected in retailer brand equity measurement models. In particular, we suggest that elements of retailer image research, which examines retailer specific aspects, can be integrated into retailer brand equity models to extend and improve the existing frameworks (for similar suggestions see Ailawadi \& Keller, 2004). It is unfortunate that such closely related research areas have not combined their knowledge and understanding but have developed separately over the years.

A further limitation of existing scales is that empirical retail brand equity studies are relatively simple and far from the complex and sequential brand building process found for example in Keller 's (2001) brand resonance framework. Often, they only capture outcomes of brand equity (e.g., Arnett et al, 2003) or they view brand equity as a two-step process with a number of image attributes leading to loyalty as in Aaker's (1996) brand equity framework. This means that our understanding of brand building in the retail industry is reduced to investigating the effects of associations on loyalty, rather than exploring how consumers evaluate, feel and act in relation to the brands and how these elements are related.

The purpose of the present study is to examine the central aspects of customer-based brand equity in retailing and to develop a more retailer specific measurement model, by integrating dimensions and attributes found in the retail image literature, in order to understand how customers evaluate retailers from a brand equity perspective.. Another ambition is to test alternative structural models found in the general brand equity literature to explicate the relationships between relevant brand equity dimensions. Additionally, in keeping with the emergence of ultra-short multidimensional scales (e.g., Geuens et al, 2009; Rammstedt \& John, 
2007), we aim to develop a parsimonious retailer brand equity scale which encompasses core brand equity dimensions alongside retail specific dimensions. Such a scale could then be used in retailer equity reseach where more dimensions and theoretical contexts need to be added without creating extensive questionnaires.

\section{Brand Equity and Retailer Equity}

Much of the research focus within the brand equity literature has been on customer perceptions, and how value is created through customer beliefs, values, and behaviors, that is customer-based brand equity. One rationale for a focus on consumer perceptions is that what customers think and do precedes, and contributes to, brand equity (Keller, 1993; Keller \& Lehmann, 2003;

Netemeyer et al., 2004; Yoo \& Donthu, 2001). How consumers perceive brands and what motivates them to act is therefore important. Brand equity research is often about understanding concrete marketing actions or assets like the brand name and how these relate to rational dimensions such as customer quality perceptions, more symbolic dimensions like brand image, and outcomes such as purchase intentions and loyalty (Aaker, 1991; Keller, 1993). With regard to the structure of general brand equity frameworks, the existing literature presents two main approaches. First, a rather simplistic approach is that all brand equity dimensions function in a parallel fashion (Aaker, 1996). The other extreme approach, presented mainly in Keller's brand resonance pyramid (2001), is more complex as it views brand building as a multi-step process consisting of salience (awareness about the brand), image and performance (perception and meaning of the brand), response (overall attitude in terms how customers feel or think), and resonance (relationship and customer loyalty). 
According to Baldauf et al., (2009) retailer equity can be defined from a customer perspective as "a set of brand assets and liabilities linked to a brand, its name and symbol, that add to or subtract from the value provided by a product or service" (2009, p. 439). Given the importance of branding for retail management, a burgeoning body of research has emerged investigating retailer brand equity. Despite the popularity of the construct, our review of this literature shows that there is no consensus as to how retailer brand equity should be measured (see Table 1). While some articles relied on a single factor with multiple items, others used multi-dimensional scales with general brand equity dimensions (e.g., awareness, associations, perceived quality, and loyalty) borrowed from mainstream frameworks (Aaker, 1991; Yoo \& Donthu, 2001; Yoo et al., 2000). An exception is the framework presented by Jara and Cliquet (2012), which attempted to incorporate more retailer specific dimensions such as personality and service, as well as a retailer image dimension (price image). Despite these extensions, this framework did not consider a loyalty dimension, which is central to most brand equity models, and the personality dimension was proposed to be unique to each retailer, thereby limiting the generalizability of the model to the other retailers or retail sectors. The retailer equity index of Arnett et al. (2003) is perhaps the purest model with regard to adopting the brand equity framework in a retail context, however as their purpose was to develop an overall retail equity scale with one factor (five items) they never tested the brand associations in a traditional sense.

Another aspect of divergence in retailer brand equity research relates to the structural relationships between the retailer equity dimensions. For example, while some researchers tested models in which retailer loyalty was the dependent variable, and the remaining dimensions (mainly awareness, associations, and perceived quality) were the predictors (Choi \& Huddleston, 2014; Jinfeng \& Zhilong, 2009), others tested frameworks in which all retailer equity dimensions 
were modeled as parallel, without any structural relationships (Das, 2015; Das et al., 2012). In their retailer equity conceptualization, Jara and Cliquet (2012) modeled awareness as the antecedent, retailer associations as the mediators, and consumer responses as the dependent variable. More recently in a study of brand-retailer-channel equity, Londoño et al, (2016) identified awareness/associations, quality, and loyalty as the formative indicators of consumerbased brand-retailer-channel equity.

The lack of clarity and consistency in the structure of retailer equity dimensions signifies the need for further research. Although the multi-step approach extends the more simplistic models, there is little evidence of attempts to investigate process-based models in the retail literature. As seen in Table 1, none of the models capture all the stages from awareness to functional and symbolic associations, as well as the customer responses that are linked to loyalty. 


\begin{tabular}{|c|c|c|c|c|c|c|c|c|c|c|c|}
\hline Article & $\begin{array}{c}\text { Single } \\
\text { Retailer } \\
\text { Equity } \\
\text { Dimension } \\
\text { (RE) } \\
\end{array}$ & $\begin{array}{l}\text { Awareness } \\
\text { (AW) }\end{array}$ & $\begin{array}{c}\text { Image } \\
\text { /Associations } \\
\text { (AS) }\end{array}$ & $\begin{array}{l}\text { Perceived } \\
\text { Quality } \\
\text { (PQ) }\end{array}$ & $\begin{array}{l}\text { Loyalty } \\
\text { (LO) }\end{array}$ & $\begin{array}{l}\text { Personality } \\
\text { (PE) }\end{array}$ & $\begin{array}{c}\text { Price } \\
\text { Image } \\
\text { /Value } \\
\text { (PI) }\end{array}$ & $\begin{array}{l}\text { Service } \\
\text { Quality } \\
\text { (SE) }\end{array}$ & $\begin{array}{l}\text { Number of } \\
\text { dimensions }\end{array}$ & Number of items & $\begin{array}{l}\text { Structural } \\
\text { Framework }\end{array}$ \\
\hline Arnett et al., (2003) & $\mathrm{X}$ & & & & & & & & 1 & 5 & - \\
\hline Baldauf et al., (2009) & & $\mathrm{X}$ & & $\mathrm{X}$ & $\mathrm{X}$ & & & & 3 & 10 & $\mathrm{RE} \rightarrow \mathrm{AW}, \mathrm{PQ}, \mathrm{LO}$ \\
\hline $\begin{array}{l}\text { Choi and Huddleston } \\
\text { (2014) }\end{array}$ & & $\mathrm{X}$ & $X$ & $\mathrm{X}$ & $\mathrm{X}$ & & & & 4 & 14 & $\mathrm{AW}, \mathrm{AS}, \mathrm{PQ} \rightarrow \mathrm{LO}$ \\
\hline Das (2015) & & $\mathrm{X}$ & $\mathrm{X}$ & $\mathrm{X}$ & $\mathrm{X}$ & & & & 4 & 12 & - \\
\hline Das, et al (2012) & & $\mathrm{X}$ & $\mathrm{X}$ & $\mathrm{X}$ & $\mathrm{X}$ & & & & 4 & 12 & - \\
\hline Gil-Saura, et al. (2013) & $\mathrm{X}$ & & & & & & & & 1 & 4 & - \\
\hline Jara and Cliquet (2012) & & $\mathrm{X}$ & & $\mathrm{X}$ & & $\mathrm{X}$ & $\mathrm{X}$ & $\mathrm{X}$ & 5 & 26 & $\begin{aligned} \mathrm{AW} \rightarrow & \rightarrow \mathrm{PQ}, \mathrm{PE}, \mathrm{PI}, \\
\mathrm{SE} & \end{aligned}$ \\
\hline $\begin{array}{l}\text { Jinfeng and Zhilong } \\
(2009)\end{array}$ & & $\mathrm{X}$ & $\mathrm{X}$ & $\mathrm{X}$ & $\mathrm{X}$ & & & & 4 & 18 & $\mathrm{AW}, \mathrm{AS}, \mathrm{PQ} \rightarrow \mathrm{LO}$ \\
\hline Londoño, et al. (2016) & $\mathrm{X}$ & $\mathrm{X}$ & & $\mathrm{X}$ & $\mathrm{X}$ & & & & 4 & 15 & $\mathrm{AW}, \mathrm{PQ}, \mathrm{LO} \rightarrow \mathrm{RE}$ \\
\hline $\begin{array}{l}\text { Pappu and Quester } \\
\text { (2006) }\end{array}$ & & $\mathrm{X}$ & $\mathrm{X}$ & $\mathrm{X}$ & $\mathrm{X}$ & & & & 4 & 15 & - \\
\hline Samu, et al (2012) & $\mathrm{X}$ & & & & & & & & 1 & 3 & - \\
\hline Swoboda, et al. (2013) & $\mathrm{X}$ & & & & & & & & 1 & 3 & - \\
\hline Swoboda, et al.(2016) & $\mathrm{X}$ & & & & & & & & 1 & 4 & - \\
\hline
\end{tabular}

Table 1: Summary of articles examining retailer brand equity dimensions. 
Retailer image research is an area with a long history of examining customer perceptions of retail stores as well as whole chains (Keaveney \& Hunt, 1992; Lindquist, 1974; Martineau, 1958; Timmermans, 1993). Despite the extant literature, conceptualization and measurement of retailer image still remains elusive. Our review of the literature incorporating retail image dimensions highlights that researchers relied on various dimensions and items to capture retailer image (see Table 2). While using different labels, the majority of this research adopted the dimensions of atmosphere, service quality, product quality, and pricing. In addition, some articles included store accessibilitylconvenience and overall brand trust or reputation dimensions.

Among the different retailer image models, the framework proposed by Burt and Carralero-Encinas (2000) stands out as being in line with the brand equity frameworks (Aaker, 1991; Aaker, 1996; Keller, 2001) as it aims to capture both functional and symbolic attributes commonly assumed to contribute to retailer identity. Furthermore, Burt and Carralero-Encinas's (2000) framework is the only retailer image model that is developed with an international perspective. We therefore posit that this is an appropriate model to be integrated into a broader retailer brand equity framework.

In summary, although retailer equity is an important research area in the literature, the scope of retailer equity dimensions and how these dimensions are related to each other within existing frameworks remains elusive. The existing frameworks are mostly based on general brand equity dimensions and measures, thereby failing to fully consider retailer specific dimensions and contexts. We contend that by integrating retailer image attributes alongside the generic brand equity dimensions (e.g., awareness and loyalty), we can increase our understanding of how customers perceive different retailers and thus contribute to a better understanding of the competitive situation in retailing. Accordingly, in this paper we aim to 
contribute to the literature by integrating brand equity and retailer image measures to re-examine the dimensions of retailer equity and how they relate to customer loyalty as the final outcome in the retailer equity building process.

\begin{tabular}{|c|c|c|c|c|c|c|}
\hline \multirow[b]{2}{*}{ Article } & \multicolumn{6}{|c|}{ Retailer Image Dimensions } \\
\hline & $\begin{array}{l}\text { Atmosphere / } \\
\text { Layout }\end{array}$ & $\begin{array}{l}\text { Product } \\
\text { Quality / } \\
\text { Selection }\end{array}$ & $\begin{array}{c}\text { Personnel / } \\
\text { Service } \\
\text { Quality }\end{array}$ & $\begin{array}{l}\text { Pricing / } \\
\text { Promotion }\end{array}$ & $\begin{array}{l}\text { Accessibility / } \\
\text { Convenience }\end{array}$ & $\begin{array}{l}\text { Reputation / } \\
\text { Brand Trust }\end{array}$ \\
\hline $\begin{array}{l}\text { Burt and Carralero-Encinas } \\
(2000)\end{array}$ & $\mathrm{X}$ & $\mathrm{X}$ & $\mathrm{X}$ & $\mathrm{X}$ & & $\mathrm{X}$ \\
\hline Chowdhury et al, (1998) & $\mathrm{X}$ & $\mathrm{X}$ & $\mathrm{X}$ & $\mathrm{X}$ & $\mathrm{X}$ & \\
\hline $\begin{array}{l}\text { Collins-Dodd and Lindley } \\
\text { (2003) }\end{array}$ & $\mathrm{X}$ & $\mathrm{X}$ & & $\mathrm{X}$ & & \\
\hline Diallo (2012) & $\mathrm{X}$ & $\mathrm{X}$ & $\mathrm{X}$ & & & \\
\hline Hildebrandt (1988) & $\mathrm{X}$ & $\mathrm{X}$ & & $\mathrm{X}$ & & \\
\hline Jinfeng and Zhilong (2009) & $\mathrm{X}$ & & $\mathrm{X}$ & $\mathrm{X}$ & $\mathrm{X}$ & $\mathrm{X}$ \\
\hline Ngobo and Jean (2012) & & $\mathrm{X}$ & $\mathrm{X}$ & $\mathrm{X}$ & $\mathrm{X}$ & $\mathrm{X}$ \\
\hline Orth and Green (2009) & $\mathrm{X}$ & $\mathrm{X}$ & & $\mathrm{X}$ & $\mathrm{X}$ & \\
\hline Semeijn, et al (2004) & $\mathrm{X}$ & $\mathrm{X}$ & $\mathrm{X}$ & & & \\
\hline $\begin{array}{l}\text { Steenkamp and Wedel } \\
\text { (1991) }\end{array}$ & $\mathrm{X}$ & $\mathrm{X}$ & $\mathrm{X}$ & $\mathrm{X}$ & & $\mathrm{X}$ \\
\hline Thang and Tan (2003) & $\mathrm{X}$ & $\mathrm{X}$ & $\mathrm{X}$ & $\mathrm{X}$ & $\mathrm{X}$ & $\mathrm{X}$ \\
\hline
\end{tabular}

Table 2: Summary of articles examining retailer image dimensions.

\section{Method}

\section{Sample and procedure}

To develop and validate an integrated retailer image and brand equity scale, primary data was collected in Sweden, a country that has several internationally renowned retailer brands such as 
H\&M and IKEA. The study was based on six well-known retailer brands in Sweden representing two different retail sectors. The first sector was grocery retailing, which represents the fastmoving consumer goods market and is sometimes defined as the convenience goods industry, and which accounts for a significant part of household spending. The second sector was interior design, which represents shopping goods. The grocery retailers in the study were ICA (The leading Swedish grocery retailer operating hypermarkets, supermarkets, and convenience stores), Willy's (a successful Swedish value-for-money big-box retailer), and Lidl (an international discount grocery store); the interior design retailers were Hemtex (a mid-market retailer), IKEA (an international value-for-money big-box retailer), and Jysk (an international discount retailer). 1056 usable web-based surveys were collected from a general population of Swedish consumers $\left(53 \%\right.$ females; $\left.M_{\text {age }}=44.09, S D=13.45\right)$. The respondents were sampled randomly by Norstat Inc, one of Europe's leading web panel companies. Panel members are continuously recruited over the telephone, and the panel is representative of Sweden as a whole in terms of gender, age, and geographical region. Each respondent answered questions regarding one of the six retailer brands in the two sectors (Grocery, $n=582$; Interior Design, $n=474$ ).

\section{Item selection and model conceptualization}

To re-examine the dimensions of retailer equity, we combined mainstream brand equity items with specific retailer image items found in the literature. The aforementioned discrepancies and limitations notwithstanding, the existing retailer equity studies relied on common sources (e.g., Arnett et al., 2003; Pappu \& Quester, 2006; Yoo et al., 2000) in developing measurement instruments. Similarly, as seen in the reviews above, several measurement items are also consistently used in the retailer image articles. In order not to divert from the literature, we chose 
to adapt previously used measures instead of developing brand new items that were not directly linked to the existing studies.

The brand equity items were adapted from the complete list of items used by Arnett et al., (2003). These items are in turn sampled from an extensive literature (Dabholkar et al, 1995; Dodds et al, 1991; Yoo et al., 2000) and represent a complete model by capturing the major dimensions of brand equity (i.e., awareness, service quality, product quality, perceived value, and loyalty). The items from Burt and Carralero-Encinas (2000) complemented the brand equity items with core retailer image-based dimensions (i.e., physical store, pricing policy, product range, customer service, character, and reputation). This scale was selected because it is wellreferenced and is one of the most comprehensive scales with regards to symbolic as well as functional retailer image items. In addition, it has an international focus and captures items relevant to convenience as well as shopping goods. In total, the measurement instrument included 41 items, which can be found in Arnett et al., (2003, p.169) and Burt and CarraleroEncinas (2000, p.452). All items were rated on a 7-point Likert-type scale $(1=$ completely disagree, 7 = completely agree).

Although there are examples of formative models of retailer equity in the literature (Arnett et al., 2003; Londoño et al., 2016), the majority of studies that examined retailer equity conceptualized retailer equity dimensions as reflective models (Choi \& Huddleston, 2014; Das, 2015; Das et al., 2012; Jinfeng \& Zhilong, 2009; Pappu \& Quester, 2006). Accordingly, in line with the existing literature, we conceptualized retailer equity as a multi-dimensional framework that is captured with first-order reflective dimensions. 


\section{Results}

The analyses in the study were conducted using covariance-based confirmatory factor analyses and structural equation modeling in AMOS 22 software. Together with the chi-square test, which tends to be significant in large sample sizes (Kline, 2005), we used the following indices with recommended cut-off values to evaluate model fit: TLI $>0.95$, CFI $>0.95$, RMSEA $<0.06$, and SRMR < 0.06 (Hu \& Bentler, 1999). Unless specified otherwise, analyses were conducted using the data aggregated for the six retailers in the study.

\section{Measurement model validation}

We first aimed to validate a new measurement model using all the items pooled from the retailer image and brand equity literature. We initially examined a model in which the items were loading onto their corresponding factors as presented in Arnett et al., (2003) and Burt and Carralero-Encinas (2000). This model resulted in an inadmissible solution. In a series of confirmatory factor analyses, we followed modification indices and also dropped cross-loading items as well as items with weak loadings (smaller than 0.50; Fornell and Larcker, 1981). After reaching an acceptable model fit, we examined the remaining items in case of semantic overlaps and, if the items conveyed similar meanings, we retained the item with the largest loading estimate. At the end of this procedure, we reached a comprehensive yet parsimonious solution with seven factors comprising seventeen items, which had a good fit to the data $\left(\chi^{2}=252.55, d f\right.$ $=98, p<.001, \mathrm{TLI}=0.99, \mathrm{CFI}=0.99, \mathrm{RMSEA}=0.04, \mathrm{SRMR}=0.02)$. The final list of items and the results of the confirmatory factor analyses for the aggregate data and the two retail sectors are presented in Table 3. 
The revised retailer equity scale included awareness (2 items), product quality (3 items), and loyalty (3 items) dimensions from the items adopted from Arnett et al., (2003). Three dimensions remained from the items adopted from Burt and Carralero-Encinas (2000): customer service (3 items), pricing policy ( 2 items), and physical store ( 2 items). Additionally, two items from Burt and Carralero-Encinas’s (2000) reputation dimension emerged as a separate factor. Because these two items captured the trustworthiness image of the retailer, we re-labeled this dimension as retailer trust.

\begin{tabular}{|c|c|c|c|c|c|}
\hline Factors and Indicators & AVE & $\mathbf{C R}$ & $\begin{array}{l}\text { AGGREGATE } \\
\text { DATASET }\end{array}$ & $\begin{array}{l}\text { GROCERY } \\
\text { RETAILERS }\end{array}$ & $\begin{array}{c}\text { INTERIOR } \\
\text { DESIGN } \\
\text { RETAILERS } \\
\end{array}$ \\
\hline Awareness & 0.47 & 0.64 & & & \\
\hline I can recognize this store among other competing stores. & & & 0.62 & 0.66 & 0.56 \\
\hline Some characteristics of this store come to mind quickly. & & & 0.75 & 0.71 & 0.81 \\
\hline Product Quality & 0.80 & 0.92 & & & \\
\hline $\begin{array}{l}\text { There is a high likelihood that merchandise bought at this store will be of } \\
\text { extremely high quality. }\end{array}$ & & & 0.92 & 0.91 & 0.93 \\
\hline Overall, this store sells high quality merchandise. & & & 0.94 & 0.94 & 0.94 \\
\hline When shopping at this store, I expect to see high quality merchandise. & & & 0.82 & 0.80 & 0.81 \\
\hline Customer Service & 0.76 & 0.91 & & & \\
\hline Store personnel are kind and helpful. & & & 0.87 & 0.87 & 0.87 \\
\hline Salespeople have a good knowledge of the products. & & & 0.84 & 0.82 & 0.88 \\
\hline This store offers a high level of customer service. & & & 0.91 & 0.92 & 0.89 \\
\hline Pricing Policy & 0.83 & 0.91 & & & \\
\hline You get good value for your money. & & & 0.91 & 0.89 & 0.93 \\
\hline The relationship between price and quality is good. & & & 0.91 & 0.93 & 0.88 \\
\hline Retailer Trust & 0.69 & 0.81 & & & \\
\hline I have total confidence in this store. & & & 0.75 & 0.73 & 0.78 \\
\hline This store never lets me down & & & 0.90 & 0.89 & 0.91 \\
\hline Physical Store & 0.83 & 0.91 & & & \\
\hline The store decor is attractive. & & & 0.85 & 0.85 & 0.89 \\
\hline The store atmosphere is excellent. & & & 0.97 & 0.94 & 0.95 \\
\hline Loyalty & 0.79 & 0.92 & & & \\
\hline I consider myself to be loyal to this store. & & & 0.88 & 0.88 & 0.89 \\
\hline $\begin{array}{l}\text { When buying the type of merchandise sold in this store, this store is my } \\
\text { first choice. }\end{array}$ & & & 0.90 & 0.90 & 0.90 \\
\hline $\begin{array}{l}\text { Even when the same items are available from other retailers, I tend to } \\
\text { buy from this store. }\end{array}$ & & & 0.88 & 0.85 & 0.90 \\
\hline
\end{tabular}

\section{Model fit indices}

Aggregate data $(n=1056): \chi^{2}=252.55, d f=98, p<.001, \mathrm{TLI}=0.99, \mathrm{CFI}=0.99, \mathrm{RMSEA}=0.04, \mathrm{SRMR}=0.02$.

Grocery retailers $(n=582): \chi^{2}=249.66, d f=98, p<.001, \mathrm{TLI}=0.97, \mathrm{CFI}=0.98, \mathrm{RMSEA}=0.05, \mathrm{SRMR}=0.03$.

Interior design retailers $(n=474): \chi^{2}=155.96, d f=98, p<.001, \mathrm{TLI}=0.99, \mathrm{CFI}=0.99$, RMSEA $=0.04, \mathrm{SRMR}=0.02$.

Table 3: Confirmatory factor analyses results of the retailer equity scale for individual retail sectors and aggregate data.

All standardized loadings are significant at $p<.001$ level. AVE $=$ average variance extracted, $\mathrm{CR}=$ composite reliability. AVE and CR values are calculated for the aggregate data. 
Convergent and discriminant validity. The convergent and discriminant validity of the measurement model was scrutinized following the guidelines presented by Fornell and Larcker (1981). The validity analyses were conducted for the aggregate data. Convergent validity is established when standardized item loadings are significant with values above 0.50 , average variance extracted (AVE) values for factors are above 0.50 , and composite reliability (CR) scores are above 0.70 (Fornell \& Larcker, 1981). As seen in Table 3, only the awareness dimension marginally deviated from the recommended values for AVE and CR. We retained this dimension to have a complete model.

Second, discriminant validity of the constructs was examined by comparing the shared variance (squared correlations) between each pair of constructs against the AVEs for these constructs (Fornell \& Larcker, 1981). In this test, discriminant validity is established when squared correlations between a pair of latent variables are smaller than the AVE of each variable. As illustrated in Table 4, the dimensions in the study had adequate discriminant validity. In further support of discriminant validity, the inter-dimension correlations were not extremely high (e.g., .90 or above; Kline, 2005) and the modification indices did not indicate model improvement via correlated item error terms.

\begin{tabular}{lcccccccc}
\hline \multicolumn{1}{c}{ Factors } & $(1)$ & $(2)$ & $(3)$ & $(4)$ & $(5)$ & $(6)$ & $(7)$ & AVE \\
\hline (1) Awareness & - & $\mathbf{0 . 1 7}$ & $\mathbf{0 . 2 6}$ & $\mathbf{0 . 4 1}$ & $\mathbf{0 . 2 6}$ & $\mathbf{0 . 2 4}$ & $\mathbf{0 . 2 4}$ & 0.47 \\
(2) Product Quality & .41 & - & $\mathbf{0 . 4 1}$ & $\mathbf{0 . 4 5}$ & $\mathbf{0 . 6 7}$ & $\mathbf{0 . 4 5}$ & $\mathbf{0 . 3 7}$ & 0.80 \\
(3) Service Quality & .51 & .64 & - & $\mathbf{0 . 3 6}$ & $\mathbf{0 . 5 5}$ & $\mathbf{0 . 5 5}$ & $\mathbf{0 . 2 6}$ & 0.76 \\
(4) Perceived Value & .64 & .67 & .60 & - & $\mathbf{0 . 6 1}$ & $\mathbf{0 . 3 2}$ & $\mathbf{0 . 4 0}$ & 0.91 \\
(5) Retailer Trust & .51 & .82 & .74 & .78 & - & $\mathbf{0 . 5 2}$ & $\mathbf{0 . 4 6}$ & 0.81 \\
(6) Physical Store & .49 & .67 & .74 & .57 & .72 & - & $\mathbf{0 . 3 4}$ & 0.91 \\
(7) Loyalty & .49 & .61 & .51 & .63 & .68 & .58 & - & 0.92 \\
\hline
\end{tabular}

Table 4: Discriminant validity analysis for the retailer equity scale. The values below the diagonal are correlation coefficients and the values in bold above the diagonal are shared variances (squared correlations). All correlations are significant $(p<0.001)$. $\mathrm{AVE}=$ average variance extracted. 
Measurement model invariance across retail sectors. Having established the validity of the extended retailer equity scale with the aggregate level data, we then sought to test whether the scale functioned similarly across individual retail sectors and whether the scale could be used to make between-sector comparisons. To answer these questions, we examined measurement invariance between the two retail sectors in the study using multiple group confirmatory factor analysis.

Following Steenkamp and Baumgartner (1998), we first assessed configural invariance, which tests the equivalence of the basic factor structure across groups. We next examined metric invariance, which tests the extent to which different groups respond to the items in a similar manner by constraining all factor loadings to equality across groups. We finally attempted to establish whether the scale can be used to compare latent factor means by examining scalar invariance. Given the sensitivity of the $\chi^{2}$ test to sample size, we compared the RMSEA values of these models to establish invariance as suggested by Nye et al., (2008). In this test, the RMSEA of the constrained model should be within the $90 \%$ confidence interval for the RMSEA of the unconstrained model to ascertain invariance.

The configural invariance model had a good fit $\left(\chi^{2}=405.60, d f=196, p<.001, \mathrm{TLI}=\right.$ $0.98, \mathrm{CFI}=0.99, \mathrm{RMSEA}=0.03290 \%$ CI $[0.027,0.036]$, SRMR $=0.03)$, indicating an equivalent factor structure for both retail sectors in the study. Similarly, the metric invariance model also had a satisfactory fit $\left(\chi^{2}=424.31, d f=206, p<.001, \mathrm{TLI}=0.98, \mathrm{CFI}=0.99\right.$, RMSEA $=0.03290 \% \mathrm{CI}[0.027,0.036]$, SRMR $=0.03)$, and a comparison of RMSEA values provided evidence of metric invariance of the model across the brands in the study. Lastly, we imposed scalar variance on the model. The initial model fit was acceptable, yet the RMSEA value of this test was outside the confidence interval of the previous metric invariance model $\left(\chi^{2}\right.$ 
$=522.68, d f=216, p<.001, \mathrm{TLI}=0.97, \mathrm{CFI}=0.98, \mathrm{RMSEA}=0.037$ 90\%CI $[0.033,0.041]$,

SRMR $=0.03$ ). Modification indices suggested relaxing the constraint on the intercept of an item from the physical store dimension. This procedure yielded an improved model $\left(\chi^{2}=475.21, d f=\right.$ $215, p<.001, \mathrm{TLI}=0.98, \mathrm{CFI}=0.98, \mathrm{RMSEA}=0.03490 \% \mathrm{CI}[0.030,0.038], \mathrm{SRMR}=0.03)$, which presented support for partial scalar invariance of the scale. Partial scalar invariance is generally accepted as a sufficient condition to compare latent factor mean scores across groups (Steenkamp \& Baumgartner, 1998).

Common method bias. When scores are obtained from a single source in cross-sectional designs, common method bias may pose a risk to the validity of the results. We examined common method bias by adding a common latent factor to the measurement model that was connected to all observed items (Podsakoff, MacKenzie, Lee, \& Podsakoff, 2003; Williams, Cote, \& Buckley, 1989). In this test, a significantly better fit for the measurement model with a common latent factor model indicates the presence of method bias (Williams et al., 1989).

We examined the discrepancies between the two models with the $90 \%$ confidence intervals of the RMSEA value. The measurement model with the common latent factor was initially unidentified due to a negative error variance, which is a common case in method bias analysis (Williams et al., 1989). After fixing the error variance of the problematic item to zero, results showed that the fit for the model with a common latent factor $\left(\chi^{2}=209.96, d f=82, p<\right.$ $.001, \mathrm{TLI}=0.99, \mathrm{CFI}=0.99, \mathrm{RMSEA}=0.03890 \% \mathrm{CI}[0.032,0.045], \mathrm{SRMR}=0.02)$ was not significantly better than the measurement model in the study $\left(\chi^{2}=252.55, d f=98, p<.001\right.$, TLI $=0.99, \mathrm{CFI}=0.99, \mathrm{RMSEA}=0.03990 \% \mathrm{CI}[0.033,0.045], \mathrm{SRMR}=0.02)$, supporting that the common method bias did not pose a threat to the validity of the model. 


\section{Structural Model Validation}

Having validated the measurement model, we subsequently examined how the dimensions in the model were related to each other. As described earlier, there are two main approaches in the literature with respect to the structure of brand equity: parallel dimensions (Aaker, 1996) and sequential dimensions (Keller, 2001). Accordingly, we began our analyses following the parallel dimensions approach and proceeded with testing models in which the dimensions resembled a sequential, multi-step process. Indirect effects were evaluated with the 90\% confidence interval of 5000 bias-corrected bootstrap samples using AMOS 22 software.

Model 1: Brand equity dimensions predict loyalty. A common model found in the literature places loyalty as the dependent variable and the remaining brand equity dimensions as the predictors (e.g., Choi \& Huddleston, 2014; Jinfeng \& Zhilong, 2009). We therefore began our analyses with this model, which is depicted in Figure 1. The parallel predictors in the model were allowed to covary. As seen in Table 5, this model had a satisfactory fit, but the path estimates were problematic (e.g., the negative estimate for customer service and nonsignificant estimate for product quality), possibly due to the correlations between the independent variables. 


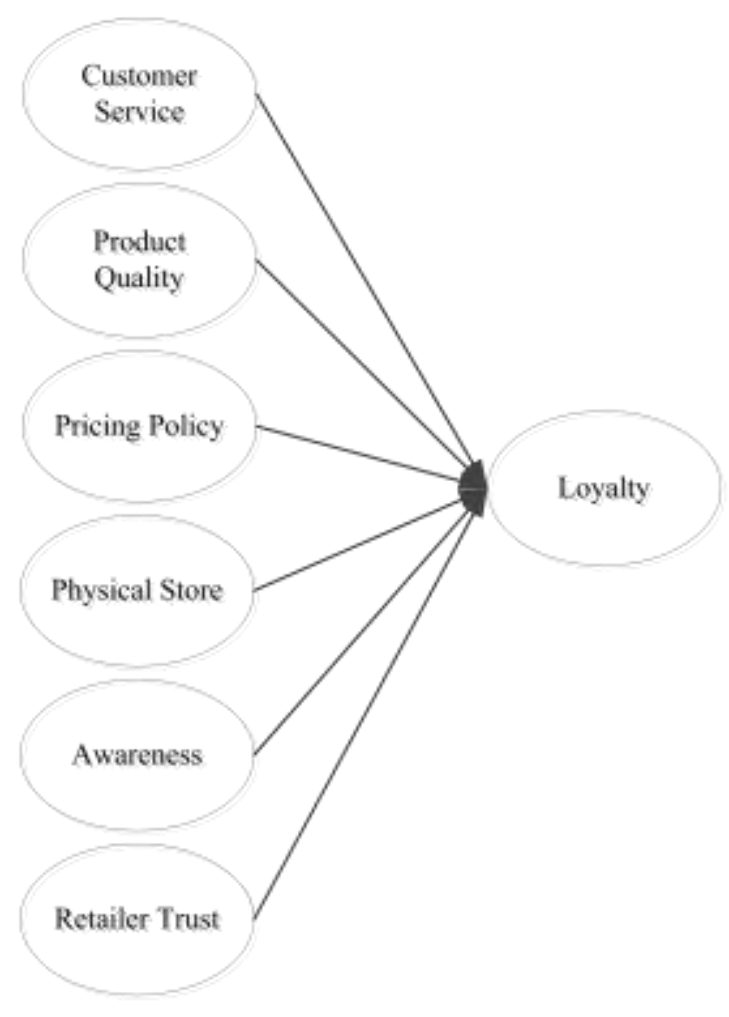

Figure 1: The conceptual diagram of model 1.

\begin{tabular}{|c|c|c|c|c|c|c|c|c|}
\hline \multicolumn{3}{|c|}{ Paths } & $B$ & $S E(B)$ & $\beta$ & $t$ & $p$ & $R^{2}$ \\
\hline Customer Service & $\rightarrow$ & \multirow{6}{*}{ Loyalty } & -0.17 & 0.07 & -0.12 & -2.48 & .013 & \multirow{6}{*}{$52 \%$} \\
\hline Product Quality & $\rightarrow$ & & 0.13 & 0.07 & 0.10 & 1.80 & .072 & \\
\hline Pricing Policy & $\rightarrow$ & & 0.23 & 0.08 & 0.17 & 2.85 & .004 & \\
\hline Physical Store & $\rightarrow$ & & 0.23 & 0.06 & 0.19 & 4.15 & $<.001$ & \\
\hline Awareness & $\rightarrow$ & & 0.25 & 0.09 & 0.13 & 2.68 & .007 & \\
\hline Retailer Trust & $\rightarrow$ & & 0.56 & 0.14 & 0.36 & 4.13 & $<.001$ & \\
\hline
\end{tabular}

Table 5: Structural equation modeling results for the first model.

Model 2: Retailer trust as the mediator. One of the ways the measurement model in this study extends previous retailer equity frameworks is the inclusion of a retailer trust dimension. Previous literature shows that customer evaluations give rise to brand trust which in turn positively influences brand loyalty (Chaudhuri \& Holbrook, 2001; Delgado-Ballester \& Munuera-Alemán, 2001, 2005). Accordingly, as seen in Figure 2, we placed retailer trust as a 
mediating variable between the remaining brand equity dimensions and loyalty in the second model. The independent variables were allowed to covary. As seen in Table 6, this model also had an adequate fit, and the parameter estimates were more meaningful than the first model. Nevertheless, this model failed to explain the role of awareness dimension in relation to the other dimensions. The awareness dimension neither had a direct effect on retailer trust (see Table 6), nor an indirect effect on loyalty $(B=-0.01,90 \% \mathrm{CI}[-0.10,0.08], p=.845)$. On the other hand, customer service $(B=0.18,90 \% \mathrm{CI}[0.12,0.24], p<.001)$, product quality $(B=0.35,90 \% \mathrm{CI}$ $[0.29,0.41], p<.001)$, pricing policy $(B=0.36,90 \% \mathrm{CI}[0.29,0.44], p<.001)$, and physical store $(B=0.14,90 \% \mathrm{CI}[0.09,0.20], p<.001)$ had significant indirect effects on loyalty through retailer trust.

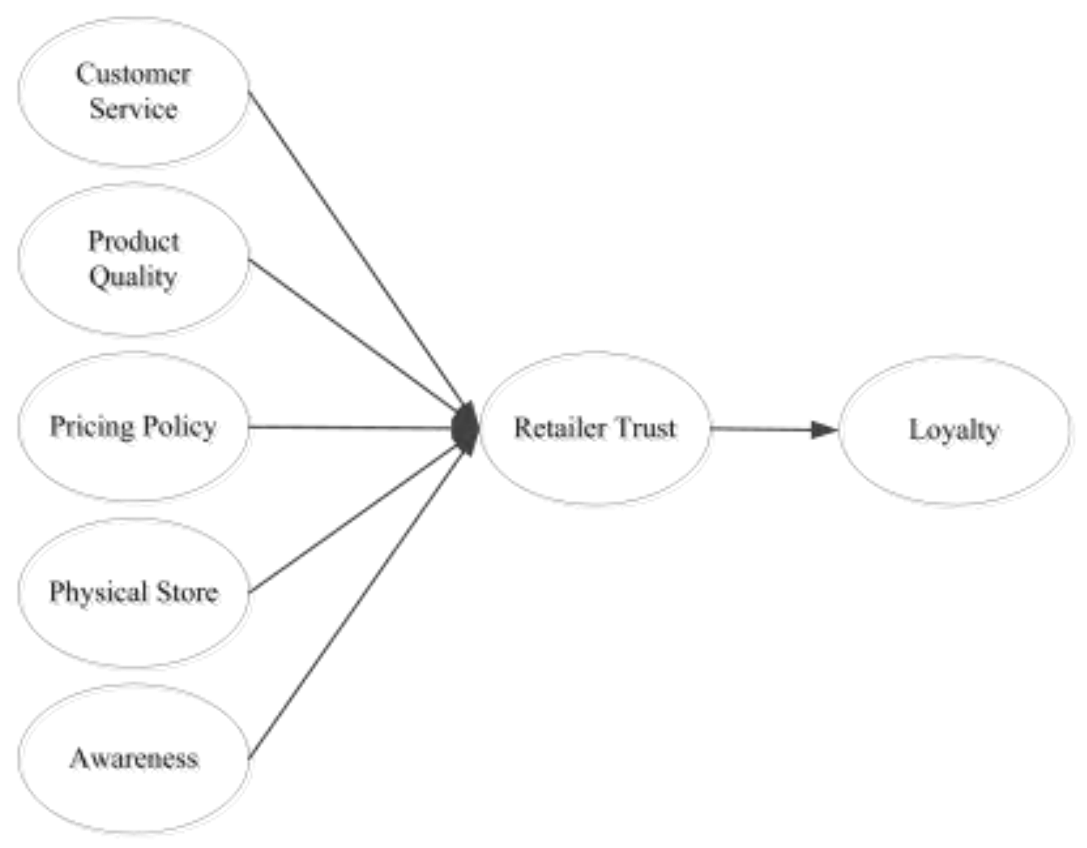

Figure 2: The conceptual diagram of model 2. 


\begin{tabular}{|c|c|c|c|c|c|c|c|c|}
\hline \multicolumn{3}{|c|}{ Paths } & $B$ & $S E(B)$ & $\beta$ & $t$ & $p$ & $R^{2}$ \\
\hline Customer Service & $\rightarrow$ & \multirow{5}{*}{ Retailer Trust } & 0.16 & 0.03 & 0.18 & 5.23 & $<.001$ & \multirow{5}{*}{$86 \%$} \\
\hline Product Quality & $\rightarrow$ & & 0.31 & 0.03 & 0.38 & 11.19 & $<.001$ & \\
\hline Pricing Policy & $\rightarrow$ & & 0.31 & 0.03 & 0.36 & 9.35 & $<.001$ & \\
\hline Physical Store & $\rightarrow$ & & 0.13 & 0.03 & 0.16 & 9.35 & $<.001$ & \\
\hline Awareness & $\rightarrow$ & & -0.01 & 0.04 & -0.01 & -0.18 & .855 & \\
\hline Retailer Trust & $\rightarrow$ & Loyalty & 1.15 & 0.05 & 0.72 & 21.21 & $<.001$ & $52 \%$ \\
\hline Model fit: $\chi^{2}=301$ & $d f$ & $3, p<.001$ & $=0.9$ & $\mathrm{FI}=0$ & $\mathrm{RM}$ & $\mathrm{A}=0 . \mathrm{C}$ & SRMF & $=0.03$ \\
\hline
\end{tabular}

Table 6: Structural equation modeling results for the second model.

Model 3: Awareness as the antecedent. To better explicate the role of awareness in our framework, we tested a third model in which the awareness dimension was modeled as an antecedent (Jara \& Cliquet, 2012). This model coincides with Keller's (2001) conceptual multistep brand resonance model, in which brand awareness is presented as the first step in brand equity building, followed by brand associations, brand responses, and brand loyalty. In the third model (see Figure 3), we tested awareness as an antecedent to the brand associations (customer service, product quality, physical store, and pricing policy). In accord with the second model, we retained retailer trust as a mediator between brand associations and loyalty. As seen in Table 7, this model also had an acceptable fit, and all path estimates were significant.

In addition, awareness had a significant indirect effect on retailer trust $(B=1.53,90 \% \mathrm{CI}$ $[1.32,1.79], p<.001)$ and loyalty $(B=1.75,90 \%$ CI $[1.52,2.07], p<.001)$. Similar to the second model, customer service $(B=0.18,90 \%$ CI $[0.12,0.24], p<.001)$, product quality $(B=0.37$, 90\%CI $[0.31,0.43], p<.001)$, pricing policy $(B=0.36,90 \%$ CI $[0.30,0.42], p<.001)$, and physical store $(B=0.14,90 \%$ CI $[0.09,0.19], p<.001)$ had significant indirect effects on loyalty in the third model. 


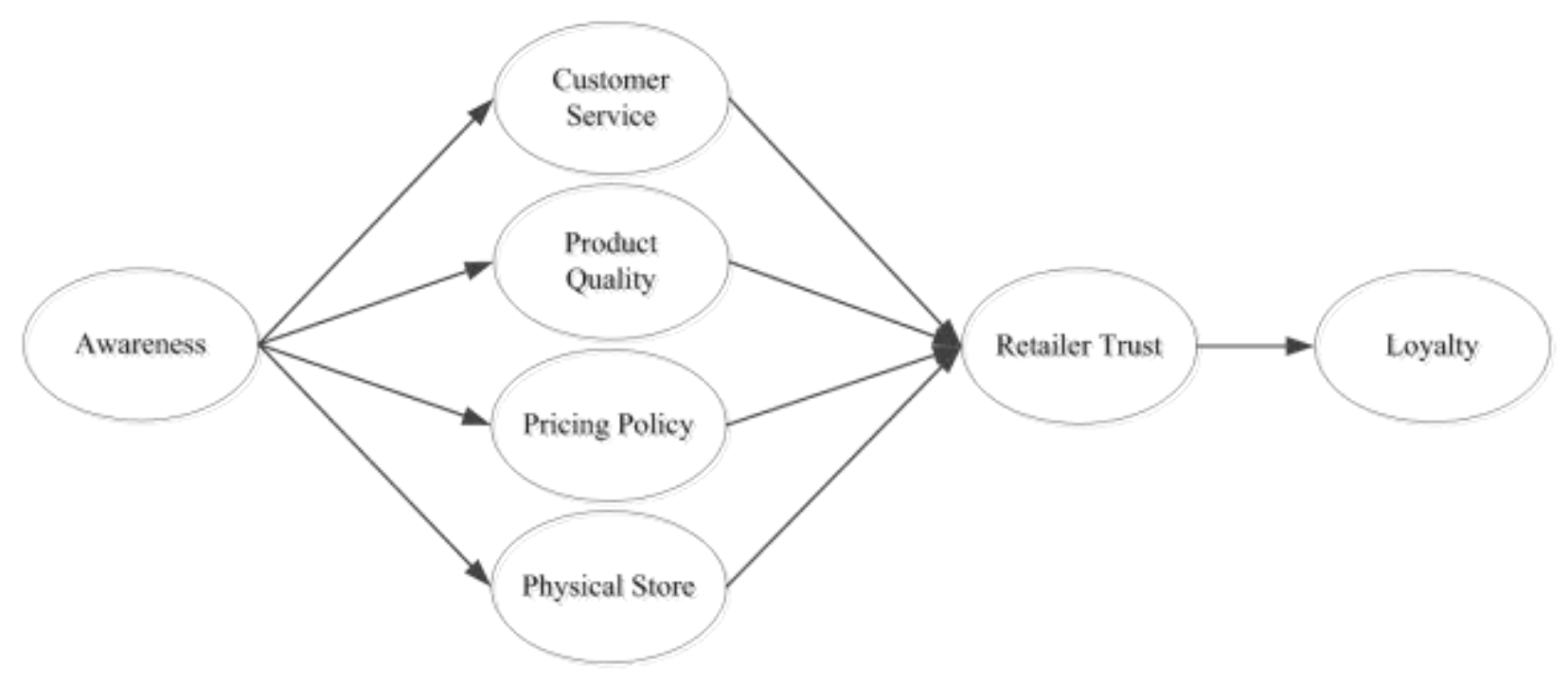

Figure 3: The conceptual diagram of model 3.

\begin{tabular}{ccccccccc}
\hline & Paths & & $B$ & $S E(B)$ & $\beta$ & $t$ & $p$ & $R^{2}$ \\
\hline & $\rightarrow$ & Customer Service & 1.66 & 0.13 & 0.83 & 12.85 & $<.001$ & $69 \%$ \\
Awareness & $\rightarrow$ & Product Quality & 1.76 & 0.14 & 0.80 & 12.90 & $<.001$ & $63 \%$ \\
& $\rightarrow$ & Pricing Policy & 1.57 & 0.12 & 0.77 & 12.65 & $<.001$ & $59 \%$ \\
& $\rightarrow$ & Physical Store & 1.89 & 0.15 & 0.82 & 12.53 & $<.001$ & $67 \%$ \\
\hline Customer Service & $\rightarrow$ & & 0.15 & 0.03 & 0.17 & 5.36 & $<.001$ & \\
Product Quality & $\rightarrow$ & Retailer Trust & 0.32 & 0.03 & 0.40 & 12.77 & $<.001$ & $86 \%$ \\
Pricing Policy & $\rightarrow$ & 0.31 & 0.03 & 0.36 & 11.49 & $<.001$ & \\
Physical Store & $\rightarrow$ & & 0.12 & 0.02 & 0.16 & 5.14 & $<.001$ & \\
\hline Retailer Trust & $\rightarrow$ & Loyalty & 1.15 & 0.05 & 0.72 & 21.14 & $<.001$ & $52 \%$ \\
\hline Model fit: $\chi^{2}=564.29, d f=110, p<.001$, TLI $=0.96$, CFI $=0.97$, RMSEA $=0.06$, SRMR $=0.04$ \\
\hline
\end{tabular}

Table 7: Structural equation modeling results for the third model.

To examine whether this model was also applicable across different retail sectors, we conducted multiple group structural equation modeling (Kline, 2005) for the two retail sectors in the study (grocery and interior design). In this test, first the structural model is estimated simultaneously for all groups (unconstrained model), then the paths are constrained to equality between groups (constrained model). Large model fit discrepancies between the unconstrained and the constrained models indicate that the parameters may be different between groups (Kline, 2005). When the model was estimated freely (unconstrained model, see Table 8), all direct and indirect path estimates were significant (all $p$ s <.01) for each sector. Moreover, a comparison of 
the RMSEA values showed that the fit for the constrained model $\left(\chi^{2}=769.72, d f=229, p<.001\right.$, $\mathrm{TLI}=0.96, \mathrm{CFI}=0.96, \mathrm{RMSEA}=0.04790 \% \mathrm{CI}[0.044,0.051], \mathrm{SRMR}=0.05)$ was not significantly different than the unconstrained model $\left(\chi^{2}=749.93, d f=220, p<.001, \mathrm{TLI}=0.95\right.$, $\mathrm{CFI}=0.96, \mathrm{RMSEA}=0.04890 \% \mathrm{CI}[0.044,0.052], \mathrm{SRMR}=0.05)$, indicating the equivalence of model parameters for each sector.

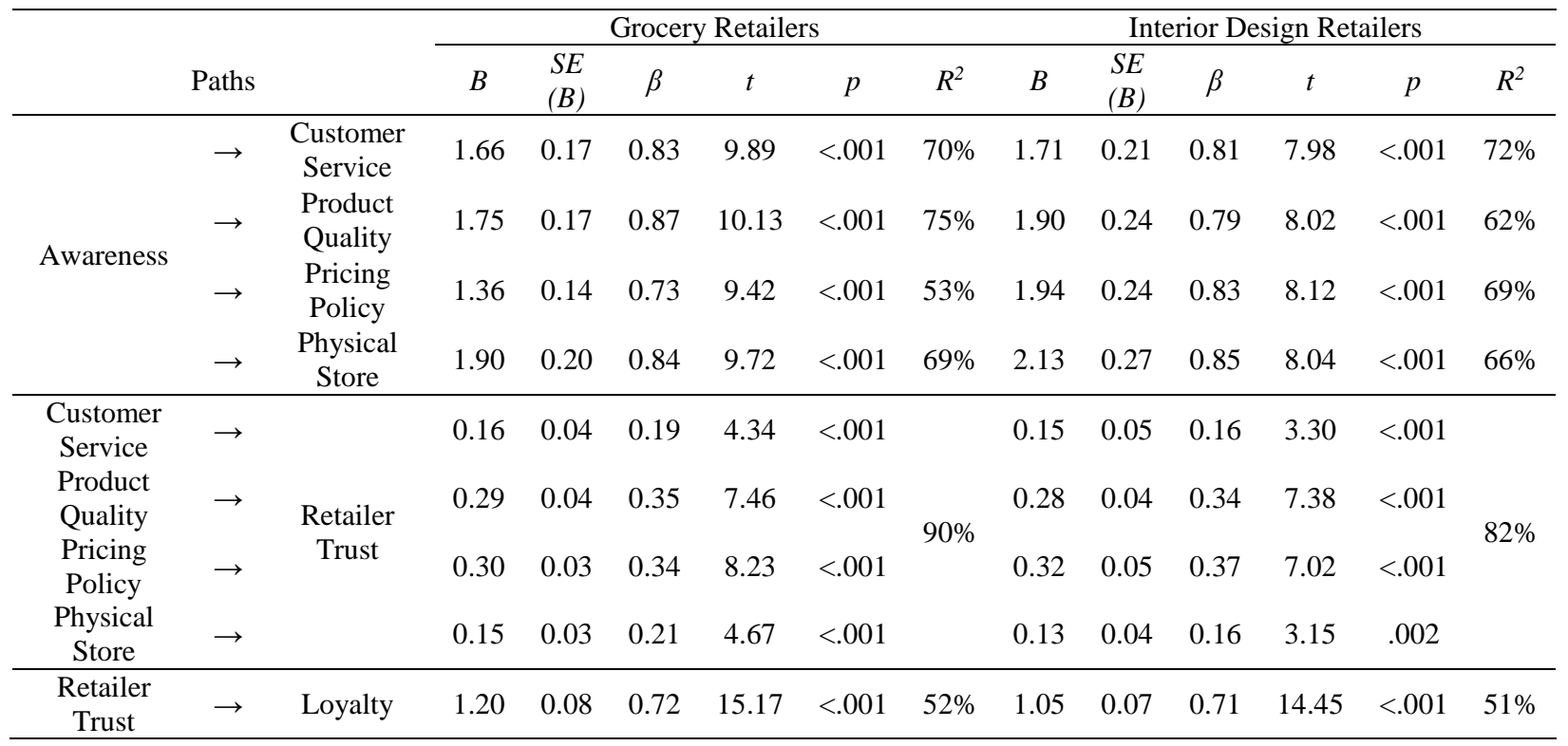

Table 8: Multiple group structural equation modeling results (all paths were estimated freely).

\section{Discussion}

In this study, we re-examined and extended the existing retailer equity frameworks by integrating brand equity and retailer image items found in the literature. The conceptual domain of the extended scale consists of seven dimensions, namely awareness, product quality, customer service, pricing policy, retailer trust, physical store, and loyalty.

So far, the mainstream brand equity frameworks focused on four main dimensions: awareness, perceived quality, associations, and loyalty. In our scale awareness and loyalty are 
present as individual dimensions. Perceived quality, on the other hand, is reflected via the dimensions of product quality, which captures customers' perceived quality of the products sold by the retailer, and customer service, which captures costumers' perceived service quality of the retailer. To justify the need for an extended retailer equity scale, we argued that the existing scales in the literature neglected retailer specific elements, especially with regard to retailer brand associations. First, with the physical store dimension, the present scale accounts for customers' perceptions of the physical store appearance, which is a key aspect of overall retailer branding (Ailawadi \& Keller, 2004; Keller, 2010) given that physical store associations contribute to brand equity as they influence customer intentions (Baker, Parasuraman, Grewal, \& Voss, 2002). Second, the extended scale captures customers' perceived price perceptions with the pricing policy dimension. Store price perceptions are central to retailer brand equity, because, mainly independent of other associations, customers take prices into consideration before making a purchase from a retailer (Ailawadi \& Keller, 2004). Third, the model holds for both categories of retailers (convenience and shopping goods) showing that price and goods are the two most significant drivers of brand trust. Finally, our scale incorporates the retailer trust dimension, which has been overlooked in other retailer equity models despite the strong association of brand trust with overall brand equity (Chaudhuri \& Holbrook, 2001; Delgado-Ballester \& MunueraAlemán, 2001, 2005). Through the trust dimension, our scale incorporates the relational aspects of retail branding. A brand is considered to have a trustworthy image when it consistently delivers value to its customers, or, in other words, when customers expect consistent positive outcomes from their relationship with the brand (Delgado-Ballester \& Munuera-Alemán, 2005). Accordingly, high levels of trust in a brand were found to be associated directly with loyalty and indirectly with market share (Chaudhuri \& Holbrook, 2001). 
In the literature, contention exists regarding how retailer equity dimensions are related to each other. An examination of three alternative models with comparable fit revealed that the model which incorporated awareness as an antecedent to brand associations (customer service, product quality, physical store, pricing policy) and with retailer trust as a mediator between brand associations and loyalty (see model 3 in Figure 1) had good explanatory power (retailer trust over $80 \%$ and retailer loyalty over $50 \%$ ).

One of the most interesting findings is perhaps that the best model accords well with Keller's (2001) four-step brand resonance framework, which has seldom been examined empirically. This sequential model puts awareness as the first step in brand equity building, followed by brand associations and customer responses, finally resulting in brand loyalty. In support of Keller's (2001) framework, we found that perceived quality should be parallel to the other image attributes, which precede retailer trust. Trust seems to be the overall attitude and response that links brand image and performance to loyalty, as conceptualized in Keller (2001).

\section{Conclusion}

The theoretical contributions of this paper can be divided into three main categories: the development of a new retailer brand equity framework by incorporting substantially theoretical store image dimensions; the confirmation of a fundamental conceptual framework by testing three alternative brand equity structures; and the provision of a parsimonious scale as a foundation for future retailer brand equity research that can incorporate other dimensions and constructs relating to retailer equity.

Development: to date, the existing empirical literature on retailer equity has focused on four mainstream brand equity dimensions - awareness, loyalty, associations, and perceived 
quality - to measure retailer brand equity. This study illustrates how brand equity can be integrated with core retailer image concepts in a way that allows researchers to better understand which associations build brand equity in retailing. We present a retailer brand equity framework and a scale based on seven dimensions that goes beyond the conventional retailer equity models by incorporating retailer specific image dimensions such as customer service, pricing policy, physical store, and retailer trust. These additional dimensions help us to better understand and explain how retailer equity can build customer loyalty. We also conclude that in turn, retail image literature could benefit by putting these image attributes in a wider context than the commonly used outcomes like store choice or satisfaction as the dependent variable.

Confirmation: by testing three alternative models and structures derived from the general literature on brand equity we have confirmed that retailer brand equity can be described and understood in a similar fashion as Keller's four step structure found in his well-known brand resonance pyramid (Keller, 2001). As far as we know this has never been done before, particularly not in retailing context. Most often it is Aaker's (1991) more simplistic brand equity structure that has been used in empirical studies rather than Keller's (2001) more sophisticated model which describes how these four dimensions are related in a four-step brand-building process. The process starts with Awareness when the customer becomes aware of the brand, which Keller (2001) terms Brand Salience. The next step is about the customer forming an image about the brand through functional or symbolic associations. These beliefs about the retailer then lead to a response in terms of an overall judgment or feeling in terms of retailer trust. Finally, the process builds relationships and overall loyalty to the retailer.

This framework or the mapping of the dimensions in current retailer equity and retail image frameworks onto Keller's framework provides the most valid structure. This structure 
provided rigorous reliability and validity analyses for the extended retailer scale using covariance-based confirmatory factor analysis and structural equation modeling. This approach has several advantages over the alternatives such as variance-based analysis (e.g., PLS). For example, covariance structure analysis accounts for measurement error, presents fit statistics to evaluate overall fit as well as allowing comparisons of alternative models, and provides diagnostic information to improve model specification (Diamantopoulos, 2011). This four-step structure helps us to better understand the relationship between the dimensions in the retailer brand equity building process.

Foundation: we present a revised and extended retailer brand equity scale, which not only provides a high predictability of core dimensions such as brand trust and loyalty, but is also comprehensive including both general brand equity dimensions and retail industry specific dimensions.. In accordance with suggestions in the literature regarding the development of short scales (e.g., Burisch, 1997), our scale consists of only 17 items, which is a reasonable number to incorporate into longer customer surveys. In this way, the scale aims at examining retailer equity without increasing respondent fatigue. This is an important contribution to retailer equity research as scholars can easily add other constructs they are interested in without creating a long questionnaire whilst still retaining the most important dimensions of retailer equity.

Managerial implications: Given the importance of strategic brand management for the retail industry, a dedicated tool to measure and support our understanding of retailer brand equity is essential. Managers should recognize that all seven dimensions presented here are critical and have some impact on purchase intentions. Today we find examples of retailer brands that have achieved global success and are well-known for distinctively positioning themselves on these dimensions: customer service (Nordstrom, Zappos), physical store (Ikea, Apple store), pricing 
policy (Wal-Mart, Lidl, Aldi), and retailer trust (Amazon), which is a novel addition to the current retailer equity frameworks. For analytical and control purposes, brand managers could compare themselves to competitors on these dimensions. If not managed well, these dimensions could become liabilities (Aaker, 1991), but if handled well, and performed better than competitors, they can be interpreted as assets. Retail managers who want to analyze and understand their brand's performance could also use the present scale for tracking the performance of competitors or assessing how their brand performs in different geographical regions, with different customer segments or over different time periods. However, the scale should be viewed as a general scale, intended to capture the dimensions relevant to the majority of customers and retailer brands. As the scale only consists of 17 items, an individual retailer could easily add other dimensions that are used to differentiate it from competitors to provide so called points-of-difference.

We share the concerns recently expressed by retail scholars with regard to the fragmented nature of retailer brand equity research and the need for future research in this area (Londoño et al., 2017). Although the present research is a step forward towards a unified retailer equity framework, there are of course certain limitations as well as opportunities for further improvements to the model presented here. We confirm much of the four-step brand equity building process presented by Keller (2001), however, although we chose to use Burt and Carralero-Encinas (2000), because their framework contained symbolic dimensions of retail image only retailer trust could be directly defined as symbolic within our resulting model. Other symbolic associations (e.g. conservative image, British appeal, world class, or serves the middle class) did not emerge as significant, maybe reflecting the differentiation strategy of the retailer under investigation or a lack of significant relationships to other items in the scale. Future 
research could try to add symbolic dimensions like user profiles, user situations etc. more systematically.

This study covers both convenience and shopping goods in various price segments, but does not address premium products. Future studies could use this framework to test the facets of price premium between premium brands or between premium and middle range brands. All brands in the study are related to companies that sell through both online and traditional channels. Future studies could test and compare the relevance of the seven dimensions as well as the adequacy of the four-step model for the specific channels. Further research is needed in this area as sequential brand building models such as the four-step model have been criticized in online contexts (Edelman, 2010). 


\section{References}

Aaker, D. A. (1991). Managing brand equity. New York: The Free Press.

Aaker, D. A. (1996). Building strong brands. London: Simon and Schuster.

Ailawadi, K. L., \& Keller, K. L. (2004). Understanding retail branding: conceptual insights and research priorities. Journal of Retailing, 80(4), 331-342.

Anselmsson, J., \& Bondesson, N. (2015). Brand value chain in practise; the relationship between mindset and market performance metrics: A study of the Swedish market for FMCG. Journal of Retailing and Consumer Services, 25, 58-70.

Anselmsson, J., Johansson, U., \& Persson, N. (2007). Understanding price premium for grocery products: a conceptual model of customer-based brand equity. Journal of Product \& Brand Management, 16(6), 401-414.

Arnett, D. B., Laverie, D. A., \& Meiers, A. (2003). Developing parsimonious retailer equity indexes using partial least squares analysis: a method and applications. Journal of Retailing, 79(3), 161-170.

Baker, J., Parasuraman, A., Grewal, D., \& Voss, G. B. (2002). The Influence of Multiple Store Environment Cues on Perceived Merchandise Value and Patronage Intentions. Journal of Marketing, 66(2), 120-141.

Baldauf, A., Cravens, K. S., Diamantopoulos, A., \& Zeugner-Roth, K. P. (2009). The Impact of Product-Country Image and Marketing Efforts on Retailer-Perceived Brand Equity: An Empirical Analysis. Journal of Retailing, 85(4), 437-452.

BrandZ. (2016). Most Valuable Global Brands. Retrieved from http://wppbaz.com/admin/uploads/files/BZ_Global_2016_Report.pdf

Burisch, M. (1997). Test length and validity revisited. European Journal of Personality, 11(4), 303-315.

Burt, S. (2000). The strategic role of retail brands in British grocery retailing. European Journal of Marketing, 34(8), 875-890.

Burt, S., \& Carralero-Encinas, J. (2000). The role of store image in retail internationalisation. International Marketing Review, 17(4/5), 433-453.

Chaudhuri, A., \& Holbrook, M. B. (2001). The Chain of Effects from Brand Trust and Brand Affect to Brand Performance: The Role of Brand Loyalty. Journal of Marketing, 65(2), 81-93.

Choi, L., \& Huddleston, P. (2014). The effect of retailer private brands on consumer-based retailer equity: comparison of named private brands and generic private brands. The International Review of Retail, Distribution and Consumer Research, 24(1), 59-78.

Chowdhury, J., Reardon, J., \& Srivastava, R. (1998). Alternative Modes of Measuring Store Image: An Empirical Assessment of Structured versus Unstructured Measures. Journal of Marketing Theory and Practice, 6(2), 72-86.

Collins-Dodd, C., \& Lindley, T. (2003). Store brands and retail differentiation: the influence of store image and store brand attitude on store own brand perceptions. Journal of Retailing and Consumer Services, 10(6), 345-352.

Dabholkar, P. A., Thorpe, D. I., \& Rentz, J. O. (1995). A Measure of Service Quality for Retail Stores: Scale Development and Validation. Journal of the Academy of Marketing Science, 24(1), 3-16. 
Das, G. (2015). Impact of store attributes on consumer-based retailer equity: An exploratory study of department retail stores. Journal of Fashion Marketing and Management: An International Journal, 19(2), 188-204.

Das, G., Datta, B., \& Guin, K. K. (2012). Impact of retailer personality on consumer-based retailer equity: An empirical study of retail brands. Asia Pacific Journal of Marketing and Logistics, 24(4), 619-639.

Delgado-Ballester, E., \& Munuera-Alemán, J. L. (2001). Brand trust in the context of consumer loyalty. European Journal of Marketing, 35(11/12), 1238-1258.

Delgado-Ballester, E., \& Munuera-Alemán, J. L. (2005). Does brand trust matter to brand equity? Journal of Product \& Brand Management, 14(3), 187-196.

Diallo, M. F. (2012). Effects of store image and store brand price-image on store brand purchase intention: Application to an emerging market. Journal of Retailing and Consumer Services, 19(3), 360-367.

Diamantopoulos, A. (2011). Incorporating formative measures into covariance-based structural equation models. MIS Q., 35(2), 335-358.

Dodds, W. B., Monroe, K. B., \& Grewal, D. (1991). Effects of Price, Brand, and Store Information on Buyers' Product Evaluations. Journal of Marketing Research, 28(3), 307319.

Edelman, D. C. (2010). Branding in the digital age. Harvard Business Review, 88(12), 62-69.

Fornell, C., \& Larcker, D. F. (1981). Evaluating Structural Equation Models with Unobservable Variables and Measurement Error. Journal of Marketing Research, 18(1), 39-50.

Geuens, M., Weijters, B., \& De Wulf, K. (2009). A new measure of brand personality. International Journal of Research in Marketing, 26(2), 97-107.

Gil-Saura, I., Ruiz-Molina, M. E., Michel, G., \& Corraliza-Zapata, A. (2013). Retail brand equity: a model based on its dimensions and effects. The International Review of Retail, Distribution and Consumer Research, 23(2), 111-136.

Hildebrandt, L. (1988). Store image and the prediction of performance in retailing. Journal of Business Research, 17(1), 91-100.

Hu, L. t., \& Bentler, P. M. (1999). Cutoff criteria for fit indexes in covariance structure analysis: Conventional criteria versus new alternatives. Structural Equation Modeling: A Multidisciplinary Journal, 6(1), 1-55.

Interbrand. (2016). Best Global Brands. Retrieved from http://interbrand.com/best-brands/bestglobal-brands/2016/ranking/

Jara, M., \& Cliquet, G. (2012). Retail brand equity: Conceptualization and measurement. Journal of Retailing and Consumer Services, 19(1), 140-149.

Jinfeng, W., \& Zhilong, T. (2009). The impact of selected store image dimensions on retailer equity: Evidence from 10 Chinese hypermarkets. Journal of Retailing and Consumer Services, 16(6), 486-494.

Keaveney, S. M., \& Hunt, K. A. (1992). Conceptualization and operationalization of retail store image: A case of rival middle-level theories. Journal of the Academy of Marketing Science, 20(2), 165-175.

Keller, K. L. (1993). Conceptualizing, Measuring, and Managing Customer-Based Brand Equity. Journal of Marketing, 57(1), 1-22.

Keller, K. L. (2001). Building customer-based brand equity. Marketing Management(July/August), 15-19. 
Keller, K. L. (2010). Brand Equity Management in a Multichannel, Multimedia Retail Environment. Journal of Interactive Marketing, 24(2), 58-70.

Keller, K. L., \& Lehmann, D. R. (2003). How do brands create value? Marketing Management, 12(3), 26-31.

Kline, R. B. (2005). Principles and practice of structural equation modeling. New York: Guilford.

Lassar, W., Mittal, B., \& Sharma, A. (1995). Measuring customer-based brand equity. Journal of Consumer Marketing, 12(4), 11-19.

Lindquist, J. D. (1974). Meaning of Image. Journal of Retailing, 50(4), 29-38.

Londoño, J. C., Elms, J., \& Davies, K. (2016). Conceptualising and measuring consumer-based brand-retailer-channel equity. Journal of Retailing and Consumer Services, 29, 70-81.

Londoño, J. C., Elms, J., \& Davies, K. (2017). A commentary on "conceptualising and measuring consumer-based brand-retailer-channel equity": A review and response. Journal of Retailing and Consumer Services, 37, 31-32.

Martin, G. S., \& Brown, T. J. (1990). In search of brand equity: the conceptualization and measurement of the brand impression construct. Marketing theory and applications, 2(1), 431-438.

Martineau, P. (1958). The Personality of the Retail Store. Harvard Business Review, 36(1), 4755.

Netemeyer, R. G., Krishnan, B., Pullig, C., Wang, G., Yagci, M., Dean, D., .. . Wirth, F. (2004). Developing and validating measures of facets of customer-based brand equity. Journal of Business Research, 57(2), 209-224.

Ngobo, P.-V., \& Jean, S. (2012). Does store image influence demand for organic store brands? Journal of Retailing and Consumer Services, 19(6), 621-628.

Nye, C. D., Roberts, B. W., Saucier, G., \& Zhou, X. (2008). Testing the measurement equivalence of personality adjective items across cultures. Journal of Research in Personality, 42(6), 1524-1536.

Orth, U. R., \& Green, M. T. (2009). Consumer loyalty to family versus non-family business: The roles of store image, trust and satisfaction. Journal of Retailing and Consumer Services, 16(4), 248-259.

Pappu, R., \& Quester, P. (2006). A consumer-based method for retailer equity measurement: Results of an empirical study. Journal of Retailing and Consumer Services, 13(5), 317329.

Podsakoff, P. M., MacKenzie, S. B., Lee, J.-Y., \& Podsakoff, N. P. (2003). Common method biases in behavioral research: A critical review of the literature and recommended remedies. Journal of Applied Psychology, 88(5), 879-903.

Rammstedt, B., \& John, O. P. (2007). Measuring personality in one minute or less: A 10-item short version of the Big Five Inventory in English and German. Journal of Research in Personality, 41(1), 203-212.

Samu, S., Lyndem, P. K., \& Litz, R. A. (2012). Impact of brand-building activities and retailerbased brand equity on retailer brand communities. European Journal of Marketing, 46(11/12), 1581-1601.

Semeijn, J., van Riel, A. C. R., \& Ambrosini, A. B. (2004). Consumer evaluations of store brands: effects of store image and product attributes. Journal of Retailing and Consumer Services, 11(4), 247-258. 
Srivastava, R. K., Shervani, T. A., \& Fahey, L. (1998). Market-Based Assets and Shareholder Value: A Framework for Analysis. Journal of Marketing, 62(1), 2-18.

Steenkamp, J.-B. E. M., \& Wedel, M. (1991). Segmenting Retail Markets on Store Image Using a Consumer-Based Methodology. Journal of Retailing, 67(3), 300.

Steenkamp, J. Benedict E. M., \& Baumgartner, H. (1998). Assessing Measurement Invariance in Cross-National Consumer Research. Journal of Consumer Research, 25(1), 78-107.

Swoboda, B., Berg, B., Schramm-Klein, H., \& Foscht, T. (2013). The importance of retail brand equity and store accessibility for store loyalty in local competition. Journal of Retailing and Consumer Services, 20(3), 251-262.

Swoboda, B., Weindel, J., \& Halsig, F. (2016). Predictors and effects of retail brand equity - A cross-sectoral analysis. Journal of Retailing and Consumer Services, 31, 265-276.

Thang, D. C. L., \& Tan, B. L. B. (2003). Linking consumer perception to preference of retail stores: an empirical assessment of the multi-attributes of store image. Journal of Retailing and Consumer Services, 10(4), 193-200.

Timmermans, H. (1993). Retail Environments and Spatial Shopping Behavior. In G. Tommy \& G. G. Reginald (Eds.), Advances in Psychology (Vol. 96, pp. 342-377): North-Holland.

Washburn, J. H., \& Plank, R. E. (2002). Measuring Brand Equity: An Evaluation of a ConsumerBased Brand Equity Scale. Journal of Marketing Theory and Practice, 10(1), 46-62.

Williams, L. J., Cote, J. A., \& Buckley, M. R. (1989). Lack of method variance in self-reported affect and perceptions at work: Reality or artifact? Journal of Applied Psychology, 74(3), 462-468.

Yoo, B., \& Donthu, N. (2001). Developing and validating a multidimensional consumer-based brand equity scale. Journal of Business Research, 52(1), 1-14.

Yoo, B., Donthu, N., \& Lee, S. (2000). An Examination of Selected Marketing Mix Elements and Brand Equity. Journal of the Academy of Marketing Science, 28(2), 195-211. 